\author{
Universidade de Brasília \\ Centro de Excelência em Turismo
}

\title{
BIODIGESTOR:
}

\section{ALTERNATIVA PARA O MANEJO DO LIXO EM AÉREAS ECOTURÍSTICAS}

\author{
Paulo Henrique de Souza Roma
}

Orientador: Sérgio Salazar Salvati

Monografia apresentada ao Centro de Excelência em Turismo da Universidade de Brasília como requisito parcial para obtenção do certificado de Especialista em Ecoturismo. 


$$
\begin{aligned}
& \text { Brasília/DF, maio } 2003 . \\
& \text { Universidade de Brasília }
\end{aligned}
$$

Centro de Excelência em Turismo

Curso de Especialização em Ecoturismo

\section{BIODIGESTOR: \\ ALTERNATIVA PARA O MANEJO DO LIXO EM \\ AÉREAS ECOTURÍSTICAS}

Paulo Henrique de Souza Roma

Banca Examinadora

Orientador

Membro da Banca

Brasília, DF, 26 de maio de 2003.

Paulo Henrique de Souza Roma 
A todas as pessoas que sempre lutam por seus objetivos e mesmo com muitas dificuldades, conseguem alcançá-los. 
São tantas as pessoas para agradecer, que sou capaz de esquecer alguém, mas pelo menos algumas eu devo citar: Verônica, Lucila, Lívia e em especial, como não poderia deixar de ser, Joana. 


\section{RESUMO}

Com o crescimento do Ecoturismo, um grande número de pessoas passaram a visitar aéreas naturais e pequenas cidades. Com o aumento dessa demanda, alguns problemas considerados de grandes cidades, começaram a ocasionar prejuízos nessas cidades, e em particular o problema com o lixo. $O$ objetivo desse trabalho é demonstrar algumas práticas e viáveis para o lixo, tais como: Reciclagem, Educação Ambiental, e principalmente o uso do Biodigestor e a utilização do biogás como fonte de energia. Demonstrando ainda a intima relação entre o ecoturismo e o destinação adequada do lixo produzido.

\section{RESUME}

With the increase of the ecoturism, a large number of people began to visit natural areas and small towns. With the enlargement of this demand, some problems considered as being from big cities began to cause losses in these cities, and mainly the problem with the garbage. The purpose of this work is to demonstrate some viable practices to the garbage. Such as: Recycling, Environmental Education, and most important the use of the biogigestor and the utilization of the Bio-gas as energy source, and still demonstrating the close relation between the Ecoturism and the adequate destination to the produced garbage. 


\section{SUMÁRIO}

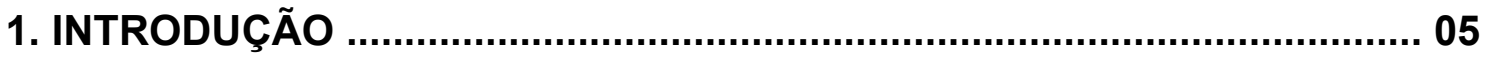

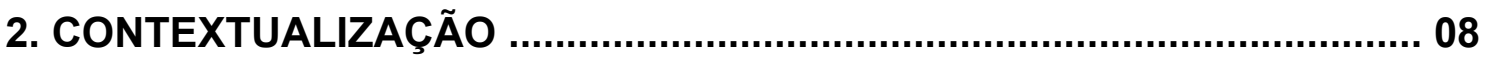

2.1. Entendendo o Ecoturismo ....................................................... 08

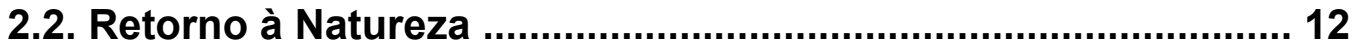

2.3. Lixo ou Matéria Prima? .............................................................. 15

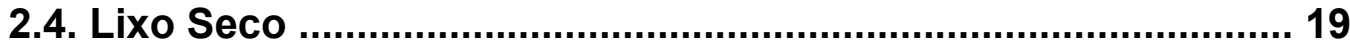

2.5. Recicla ...................................................................................... 20

2.6. Educação Ambiental ........................................................... 21

2.7. Biodigestor - Alternativa Viável ......................................... 24

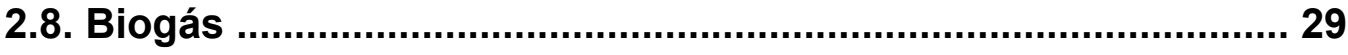

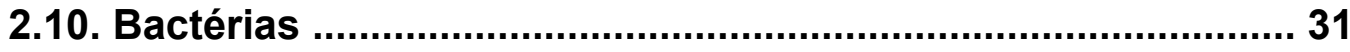

2.11. O Biofertilizante .................................................................... 31

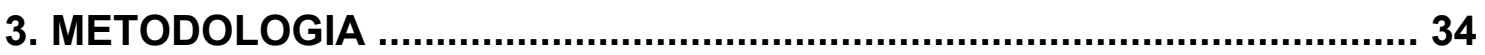

4. RESULTADOS DA DISCUSSÃO ........................................................ 35

4.1. Uso do Biogás ......................................................................... 35

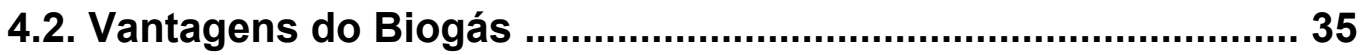

4.3. Vantagens do Biogás para o Ecoturismo ................................. 36

4.4. Alternativas para o Lixo ............................................................ 37

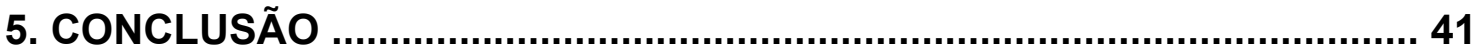

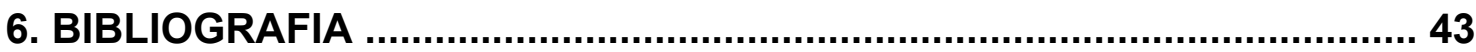




\section{INTRODUÇÃO}

Nos últimos anos o mundo viu o crescimento da chamada "Indústria do Turismo". O crescimento do número de pessoas viajando entre cidades, estados, países e até mesmo entre continentes é surpreendente. Com isso o mundo se tornou menor, as distâncias foram encurtadas e o tempo de uma viagem diminuiu, permitindo assim um fluxo de pessoas muito maior. As mais distantes cidades entre si, hoje parecem ser vizinhas.

Turistas do mundo inteiro, das mais diversas nacionalidades, pessoas de diferentes países e culturas se encontram em lugares, onde antigamente parecia impossível de acontecer. Quem imaginou um neozelandês sair de sua terra para navegar no Rio Amazonas ou um americano patriota e aficionado por aviões, viajar até a Rússia para pilotar um MIG-29, avião de caça russo mais avançado e temido durante o período da "Guerra Fria".

O Mundo mudou e o turismo ajudou nessas mudanças. Como uma criança que cresce e modifica o seu comportamento durante os anos de crescimento, o mesmo vem acontecendo com o movimento turístico ao longo dos anos. O turismo cresce e nesse processo de amadurecimento, tem sofrido mudanças e alterações. Novos estudos são realizados e novos segmentos do turismo são criados, abrindo novas fronteiras e oportunidades de negócios. Mas quem determina essas mudanças e oportunidades é o mercado. Em outras palavras, quem determina tais mudanças é o próprio turista.

O turista passou a enxergar um novo destino para as suas viagens, a natureza, repleta de belezas cênicas, cheia de vida e fascinantes espécimes de fauna e flora, e ainda a cultura de populações tradicionais que vivem harmonicamente com o ambiente natural.

As pessoas passaram a perceber que os mesmos problemas que ocorriam em suas cidades de origem, se repetiam nas cidades de destino de suas viagens. Transito, barulho, violência e poluição, são somente alguns 
exemplos de fatores estressantes dos quais as pessoas "fogem" em suas férias ou períodos de descanso.

A procura por áreas naturais como destino é justamente a busca para se afastar, nem que por um período curto de tempo, de tais problemas. É certo afirmar que quem busca a natureza para descansar e relaxar não gostaria de encontrar um ambiente sujo, degradado ou poluído.

O problema do lixo também é "internacionalizado". Esse problema é mundial e afeta todas as cidades, até mesmo pequenas localidades.

A preocupação em dar uma destinação adequada ao lixo se faz necessária e é de grande importância para o sucesso de um empreendimento ecoturístico. Uma localidade turística ou ambiente natural limpo é muito mais prazeroso, adequado e procurado por visitantes.

Soluções simples e de baixo custo podem ser aplicadas para reverter uma situação, onde o lixo esteja atrapalhando ou impedindo o desenvolvimento de uma visitação equilibrada. O fato de o ecoturismo ser desenvolvido em comunidades pequenas, ou próximo das mesmas, facilita na conscientização da comunidade. Esse trabalho de conscientizar é o primeiro passo para lidar com o problema do lixo. Um programa de educação ambiental é primordial e essencial para mostrar a população os perigos e benefícios que podem ser gerados a partir do lixo.

A coleta seletiva e a reciclagem de materiais, devem fazer parte do programa de educação ambiental, aliado à informações pertinentes sobre a conservação e preservação do ambiente. Um programa em nível elevado que consiga derrubar alguns paradigmas e ajudar na mudança de alguns comportamentos que sejam nocivos ao ambiente.

Porém o principal do trabalho é a utilização de biodigestores. 0 biodigestor é uma solução viável para a questão do saneamento e tratamento 
de esgoto, além de agregar um valor e trazer benefícios financeiros, ecológicos e sociais.

O objetivo desse trabalho é o de apresentar o Biodigestor como uma solução no manejo do lixo em localidades ecoturísticas. Aliados ao Biodigestor, falaremos de Educação ambiental, coleta seletiva, reciclagem de materiais, como fatores importantes para o manejo do lixo. 


\section{CONTEXTUALIZAÇÃO}

\subsection{Entendendo o Ecoturismo}

Antes de qualquer coisa, o ecoturismo é uma atividade sócioeconômica e para que tal atividade seja desenvolvida e praticada ela deve ser economicamente viável. Segundo especialistas, o ecoturismo é a atividade turística que mais cresce no mundo. Vejamos alguns exemplos:

"Há bons exemplos de ecoturismo gerando renda e justificando a conservação de áreas naturais. No Quênia, o sucesso do ecoturismo tem feito com que o governo crie e mantenha grandes áreas protegidas. 0 retorno total do ecoturismo desenvolvido nesses Parques Nacionais soma US\$ 40,00 por hectares, comparado a US\$ 0,80 por hectare se a terra fosse usada para agricultura (...). (...) Em Ruanda, os turistas que desejam ver os gorilas do Parque Nacional dos Volcans gastam, anualmente US\$ 1 milhão em ingressos e US\$2 a 3 milhões em gastos indiretos. Antes da implantação do ecoturismo, esses gorilas quase foram extintos pela caça predatória (...). (...) Em 1993, o sistema de Parque Nacionais dos Estados Unidos, que é considerado a maior rede de atrações turísticas naturais do mundo, recebeu mais de 270 milhões de visitantes, gerando US\$ 10 bilhões em divisas, 10 vezes mais do que gasta o Serviço de Parques Nacionais Americanos para manter e administrar essas aéreas" (Rocha. Linsker, 1996:10-11)

Como podemos perceber a atividade de ecoturismo pode ser lucrativa e viável e muitas vezes, como no caso de Ruanda, desempenha o seu papel primordial, que é o de contribuir para a conservação de áreas naturais e acarretar benefícios às comunidades. 
Para compreendermos o que é ecoturismo, o melhor é defini-lo. Porém, antes de abordarmos o tema proposto, faremos uma pequena introdução sobre segmentação de mercado, pois o ecoturismo é um nicho do mercado turístico.

Segundo Kotler, "o mercado consiste em todos os consumidores potenciais que compartilham de uma necessidade ou desejo específico, dispostos e habilitados para fazer uma troca que satisfaça essa necessidade ou desejo" (Ignarra, 1999: 75).

O objetivo de segmentar o mercado é, portanto, poder oferecer um produto específico para um grupo de pessoas que compartilham de uma mesma necessidade ou desejo. "Segmentar o mercado significa dividi-lo em grupos homogêneos de compradores e produtores" (Ignarra, 1999: 78 ).

Não adianta formatar um produto turístico, por mais que partamos de uma idéia brilhante e original, se esse produto for oferecido para o público errado. O seu investimento será um fracasso total, perdendo tempo e dinheiro. Por isso a importância de segmentar o mercado, identificando o consumidor em potencial do seu produto.

A segmentação mercadológica é fundamental em estratégias de marketing. Não é de interesse aprofundar nesse assunto, e sim, deixar claro que o ecoturismo é um dos segmentos dentro de um universo maior, que é o turismo.

Hoje, o mercado turístico está separado em diversos segmentos, com o objetivo de promover produtos específicos a grupos homogêneos: Turismo religioso, turismo de melhor idade, turismo para jovens, turismo para solteiros (singles), turismo de elite, turismo de negócios, turismo cientifico, turismo rural, turismo de aventura e o ecoturismo, que é de nosso interesse. 
Definir ou conceituar ecoturismo, não tem sido uma tarefa nada fácil, diversos autores, professores e estudiosos desenvolveram os seus conceitos. Uma diversidade de pessoas e nas mais diferentes áreas do conhecimento, desenvolveram conceitos para o ecoturismo, todos semelhantes, porém nenhum completo ou definitivo.

Para que possamos entender essa atividade, seguem abaixo alguns dos conceitos mais utilizados:

"Ecoturismo é uma atividade que proporciona ganhos financeiros e qualitativos. É alternativa de negócios, uma fonte de renda capaz de substituir a agropecuária e a exploração de madeiras, o rendimento virá com as receitas de hospedagem, alimentação, serviços e entrada aos atrativos naturais" JUSTIANO, 1999.

'Ecoturismo, em outras palavras, envolve tanto um sério compromisso com a natureza como responsabilidade social. Essa responsabilidade deve ser assumida também pelo viajante. A expressão viagem responsável, outra designação para ecoturismo, envolve objetivos semelhantes. The Ecotourism Society oferece uma definição um pouco mais completa: "Ecoturismo é a viagem responsável a áreas naturais, visando preservar o meio ambiente e promover o bem-estar da população local"' (Lindberg. Donald,. 1999: 17).

"Ecoturismo é um segmento da atividade turística que utiliza, de forma sustentável, o patrimônio natural e cultural, incentiva sua conservação e busca a formação de uma consciência ambientalista através da interpretação do ambiente, promovendo o bem-estar das populações envolvidas" (MICT/MMA, 1995: 19).

Esses são apenas alguns exemplos de conceito que foram criados para tentar definir o que é ecoturismo. 
Para efeito de estudo, vamos adotar o conceito do Ministério do Meio Ambiente de 1995. Porém o ecoturismo é bem mais que uma atividade econômica ou uma forma de conservação da natureza, isso precisa ser entendido. O ecoturismo é uma atividade sócio-cultural, é financeiro, é espiritual, é coletiva e ao mesmo tempo individual, é um estilo de vida e também uma necessidade humana.

O ecoturismo é chamado dessa forma, pois basicamente, são atividades turísticas (visitação) que são realizadas em áreas naturais, sendo assim, envolve fatores humanos, naturais e financeiros.

São diversos os fatores que motivam o homem moderno a procurar em seu período de descanso e lazer as atividades ecoturísticas. Pode ser pelo estresse causado pelo dia a dia vivenciado por todos que vivem em grandes centros urbanos, ou por querer se afastar da poluição da cidade, para poder descansar em ambiente calmo e tranqüilo, ou ainda por ser um amante da natureza. Todos os motivos levam ao mesmo lugar, ambientes naturais conservados ou que tenham simplesmente uma beleza cênica, como as águas de uma linda cachoeira que cai de seu paredão e corre ao longo do leito do rio. Além das definições acima, existem muitas outras, porém, nenhuma dessas definições se aproxima da realidade. Mas isto é assunto para um outro trabalho.

Abrindo um pequeno parêntese. É comum se observar uma certa confusão entre áreas de conservação e áreas de preservação. As Unidades de Conservação que necessitam de plano de manejo, delimitam suas áreas de conservação e preservação.

A diferença básica entre essas áreas é que a área de preservação é intangível, é restrita e não pode ser visitada, sem autorização do diretor da U.C. As áreas de conservação são abertas aos visitantes. É onde ocorre o ecoturismo. 
Outro tema relevante ao ecoturismo, é a busca do homem por áreas naturais, o "fenômeno" chamado de retorno à natureza. Tal fenômeno, pode propiciar esclarecimentos a respeito do movimento ecoturístico

\subsection{Retorno a Natureza}

Nos últimos anos, o número de turistas que visitam áreas naturais tem aumentado de forma surpreendente. Porém, esse "retorno a natureza" não é um movimento recente. A percepção que o homem tem da natureza vem se modificando com o passar do tempo. No século XVIII, a natureza, em seu estado natural, era desagradável aos homens. O bom e belo eram os campos cultivados. O uso da terra era exclusivo para a sua sobrevivência, o homem cultivava, plantava e colhia, tirando da terra o seu sustento.

No início do século XIX, essa visão começou a ser alterada. Fortemente impulsionadas pela Revolução Industrial, as fábricas modificaram a paisagem dos grandes centros urbanos. Suas chaminés começaram a lançar fumaça e fuligem no ar, deixando-o irrespirável. As cidades se tornaram cinzas e poluídas, aliado a isso houve um rápido crescimento urbano e populacional. $O$ homem passou a buscar no campo o seu refúgio para descanso e fuga da poluição das cidades. Passou a buscar o verde. Quanto mais primitiva a área natural, mais inspiradora se tornava. A natureza passou a ser um lugar de reflexão, isolamento e contemplação.

Mais recentemente, já na década de 70 , começaram a surgir os primeiros movimentos de ambientalistas, que alertavam sobre o mau uso dos recursos naturais e mostravam ao mundo os abusos cometidos pelos homens, desencadeando assim um novo conceito, o de conservação e preservação do meio ambiente.

O turismo de natureza não é uma atividade recente, há mais de um século os visitantes lotavam os primeiros Parque Nacionais americanos. Como resultado desse crescimento, nos anos 80 surge o conceito de ecoturismo, 
demonstrando a preocupação de um desenvolvimento ordenado e de conservação das áreas naturais que seriam visitadas.

No Brasil o Jardim Botânico teve sua origem em 1808. Inicialmente aberto como centro de pesquisa sobre a Mata Atlântica e a Amazônia brasileira, tornou-se Horto Real e foi aberto para visitação pública em 1922.

É evidente que a relação do homem com a natureza está sendo reavaliada.

Célia Maria de Toledo Serrano ${ }^{1}$, escreve o seguinte:

"desejo que vem se traduzindo em algumas buscas como, por exemplo, a obsessão pela proteção da natureza, a valorização e a tentativa de salvaguarda dos saberes de comunidades tradicionais - considerados como elementos necessários para a reformulação das posturas predatórias da sociedade mais ampla em relação ao ambiente - ou, ainda, a tentativa quase literal de reencontrar a natureza por meio do turismo, especialmente em sua variação "ecológica" ou "ambiental".

A Expressão "retorno à natureza" é bastante utilizada, porém, o seu real significado, ainda não foi interpretado de uma forma correta.

Nenhum ser humano, de fato, está disposto ou realmente vai retornar à natureza. Dificilmente alguém, deixará de lado o conforto que a vida moderna oferece e vai se embrenhar em mata ou floresta e ali tentar sobreviver. Tirando da terra o seu sustento, alimentação, proteção, etc.

Na verdade a expressão correta deveria ser, fuga até a natureza, visita à natureza ou mesmo turismo ${ }^{2}$ na natureza. Todas as expressões têm uma

\footnotetext{
${ }^{1}$ Historiadora, pesquisadora do Núcleo de Estudos e Pesquisas Ambientais (Nepam) Unicamp e Doutoranda em Ciências Sociais na mesma universidade.
} 
conotação de retorno. Vou à natureza, visito, tenho um contato mais próximo, durante um período determinado, mas volto para a segurança do lar, as tarefas do cotidiano. É uma visita superficial, serve para espairecer, deixar de lado a rotina do dia-a-dia. Satisfaço o meu desejo, desenvolvo atividades diferentes das comuns, pratico o ecoturismo, mas volto à cidade e retorno às atividades do cotidiano.

Os aspectos que levam os homens a buscarem a natureza são os mais variados possíveis e são individualizados, mas existe um grande fator que fará a diferença entre os locais escolhidos a serem visitados pelo ecoturista, esse fator é o lixo. Ninguém está disposto a visitar locais sujos e muito menos a pagar por isso.

A produção de lixo é diária e inevitável, pode causar uma série de problemas e até mesmo determinar a "morte" de um empreendimento ecoturístico. Em contrapartida, se a destinação dos resíduos for levada a sério e tiver um tratamento adequado, com um bom planejamento, o que seria um problema, pode ser tornar uma ótima oportunidade de negócios, gerar renda e emprego, movimentar a economia, reduzir gastos e principalmente atrair os visitantes.

A reciclagem do lixo, como o plástico, papel e garrafas é uma realidade e pode trazer grandes benefícios.

A problemática com o esgoto e matéria orgânica, é bem mais complicada, pois o ecoturismo é praticado em áreas naturais, distante de grandes centros urbanos e envolve pequenas comunidades, mas a implementação e com o bom manuseio de biodigestor, pode-se criar uma solução definitiva para o problema de esgoto, gerando diversos benefícios para toda comunidade.

\footnotetext{
${ }^{2}$ Turismo é originária da palavra Tour que é de origem francesa, referia-se a um tipo especial de viagem e eqüivale, no inglês a turn, e no latim a tornare, significando volta, retorno (Barreto, 1997: 43).
} 
Para isso temos que conhecer as características do que chamamos de lixo, e que na verdade poderíamos chamar de matéria prima.

\subsection{Lixo ou Matéria Prima?}

A palavra lixo é derivada do termo latim $L I X$, que significa "cinza" . No dicionário é definida como sujeira, imundice, coisas inúteis, velhas e sem valor. Em termos técnicos, lixo é sinônimo de resíduos sólidos e é representado por materiais descartados pelas atividades humanas.

Desde muito tempo atrás o homem produz lixo, que era constituído essencialmente de sobra de alimentos. Essa sobra era produzida em pequenas quantidades e rapidamente absorvido pela própria natureza. A partir do século XVIII, com a Revolução Industrial, as fábricas passaram a produzir objetos de consumo em larga escala e a introduzir novas embalagens no mercado, aumentando assim o número de resíduos gerados nas cidades. O homem começou então a conviver com os produtos chamados de "descartáveis" e com o aumento de lixo produzido começaram a surgir novos problemas.

Com o aumento acelerado das cidades e proporcionalmente o aumento de resíduos, as áreas disponíveis para colocação do lixo ficaram cada vez mais escassas. A sujeira acumulada no ambiente aumentou a poluição do solo, das águas e piorou as condições de saúde das populações em todo o mundo, especialmente nas regiões menos desenvolvidas.

No Brasil, a maior parte dos resíduos recolhidos nos centros urbanos é simplesmente jogada a céu aberto, sem qualquer tipo de cuidado, é geralmente colocados em depósitos existentes nas periferias das cidades.

Para que possamos entender a dinâmica do lixo, precisamos conhecer a sua classificação ${ }^{3}$ :

\footnotetext{
${ }^{3}$ Fonte: www.lixo.com.br/home.html
} 
Lixo Urbano: Formado por resíduos sólidos em áreas urbanas, incluindo os resíduos domésticos, os efluentes industriais domiciliares (indústrias de fundo de quintal) e resíduos comerciais.

Lixo Domiciliar: Formado por resíduos sólidos de atividades residenciais, contém também muita quantidade de matéria orgânica, plástico, lata e vidro.

Lixo Comercial: Formado pelos resíduos sólidos das áreas comerciais, composto por matérias orgânicas, papéis e plástico de vários grupos.

Lixo Público: Formado por resíduos sólidos a partir da limpeza pública (areia, papéis, folhagem, poda de árvores, etc.)

Lixo Especial: Formado por resíduos geralmente industriais, merece tratamento, manipulação e transporte especial, são eles: pilhas, baterias, embalagens de agrotóxicos, embalagens de combustíveis, de remédios ou venenos.

Lixo Industrial: Nem todos os resíduos produzidos, podem ser designados como lixo industrial. Algumas indústrias do meio urbano produzem resíduos semelhantes ao doméstico, exemplo disto são as padarias, que poderão ser enquadrados como lixo especial e ter a mesma destinação do lixo urbano.

Lixo de Serviço de Saúde (RSSS): Os serviços hospitalares, ambulatórios, farmácias, são geradores dos mais variados tipos de resíduos sépticos, resultados de curativos, aplicação de medicamentos que em contato com o meio ambiente ou misturado ao lixo doméstico poderão ser patógenos ou vetores de doenças, devem ser destinados à incineração. 
Lixo Atômico: Produto resultante da queima de combustível nuclear, composto de urânio enriquecido com isótopo atômico 235. A elevada radioatividade constitui um grave perigo à saúde da população, por isso deve ser enterrado em local próprio e inacessível.

Lixo Radioativo: Resíduos tóxicos e venenosos formado por substâncias radioativas resultantes do funcionamento de reatores nucleares. Como não há lugar seguro para armazenar esse lixo radioativo, a alternativa recomendada pelos cientistas foi colocá-lo em tambores ou recipientes de concreto impermeáveis e a prova de radiação, e enterrados em terrenos estáveis, no subsolo.

Como podemos observar, existe uma enorme variedade de lixo e a sua classificação está baseada na forma em que os resíduos são produzidos.

O Brasil produz cerca de 241.614 toneladas de lixo por dia. A cada dia um brasileiro produz entre 800 e 1000 gramas de lixo por dia. ${ }^{4}$

\section{Destinação do lixo no Brasil ${ }^{5}$ :}

$76 \%$ são depositados a céu aberto em lixões.

$13 \%$ são depositados em aterros controlados.

$10 \%$ são depositados em aterros sanitários.

0,9\% são compostados em usinas.

$0,1 \%$ são incinerados.

\footnotetext{
${ }^{4}$ Dados obtidos no seguinte site: http://www.recycle.hpg.ig.com.br/index.html

${ }^{5}$ Dados obtidos no seguinte site: http://www.recycle.hpg.ig.com.br/index.html
} 


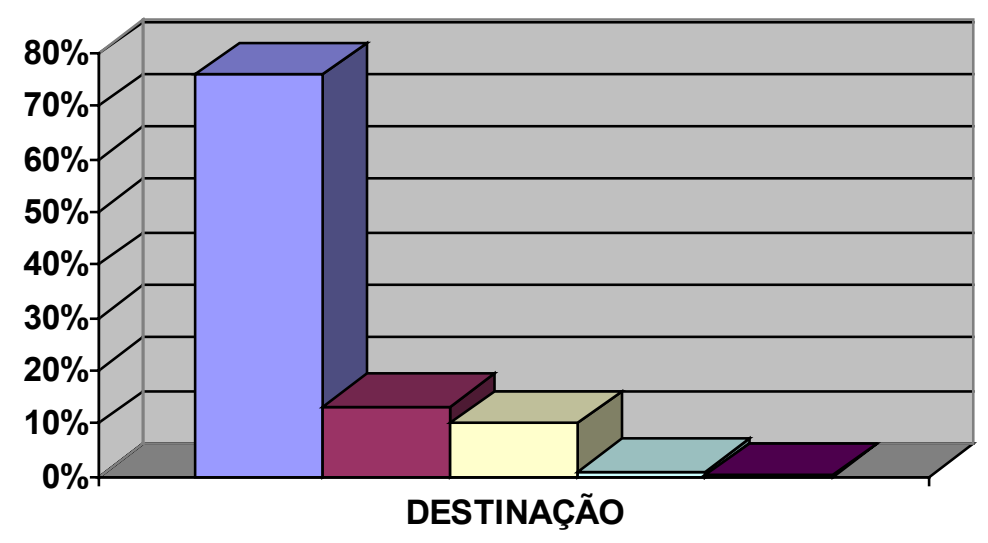

\section{口Lixão}

$\square$ Aterros Controlados

$\square$ Aterros Sanitários

$\square$ Compostados em Usinas

- Incinerados

\section{Composição do lixo domiciliar:}

$65 \%$ matéria orgânica

$25 \%$ papel

$4 \%$ metal

$3 \%$ vidro

$3 \%$ plástico

Obs.: $53 \%$ deste total é resto de comida desperdiçada.

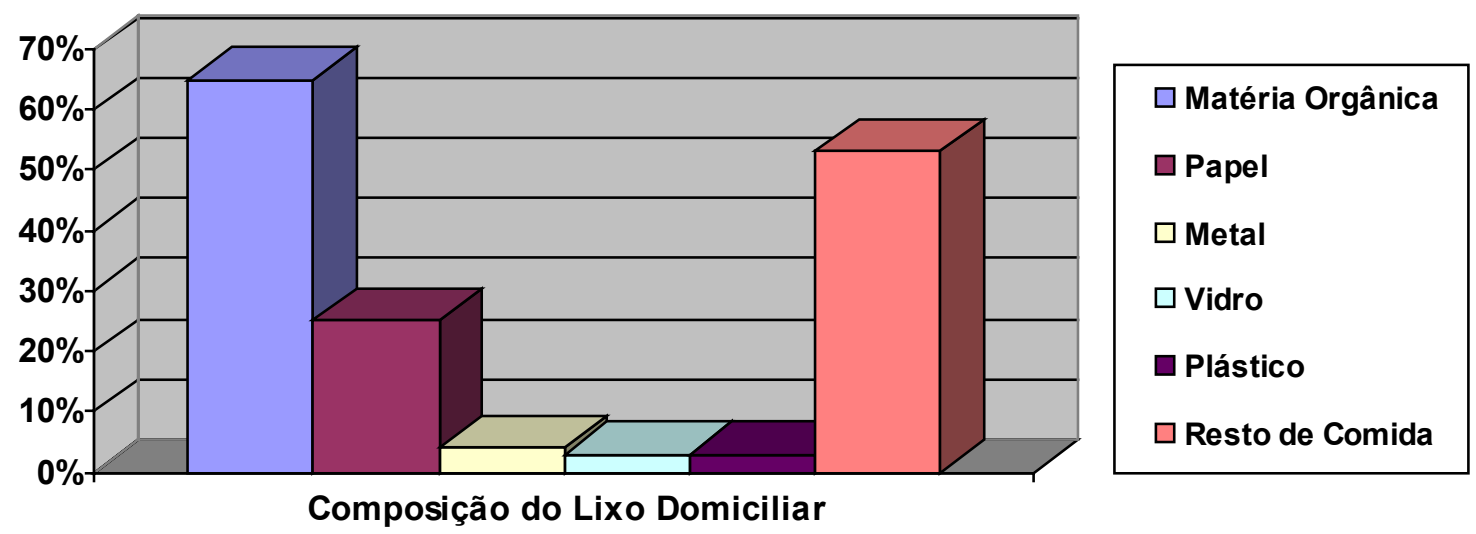

O Brasil, produz diariamente uma grande quantidade de lixo e o pior é que a sua destinação é errada. Segundo o economista Sabetai Galderoni "lixo não existe", ele afirma que nem tudo que é jogado fora possa ser aproveitado como comida, mas todo o lixo pode ser aproveitado de alguma forma.

\footnotetext{
${ }^{6}$ Professor da Universidade de São Paulo, maior especialista brasileiro em lixo e conselheiro da ONU no assunto e autor do livro Os Bilhões Perdidos no Lixo.
} 
O maior desperdício é o não aproveitamento do lixo orgânico, que geralmente provem dos restos de alimento. Esse lixo poderia ser transformado em algo útil, através de um processo chamado de compostagem. Nele o lixo sofre a ação de bactérias, e o resultado é a produção de gás metano ou biogás e a parte sólida é um excelente adubo orgânico, livre de qualquer tipo de agrotóxico.

É o fato de se "jogar fora" que está errado. Na verdade o lixo produzido nas cidades, indústrias, hospitais, etc., ele somente é mudado de lugar, sai de nossas casa e vai parar em algum aterro, sem o menor tratamento ou cuidado.

Esse é um problema que atinge todas as cidades, grandes ou pequenas, proporcionalmente. Em ambos os casos a reciclagem do material é uma alternativa viável, correta e economicamente favorável. Em pequenas cidades ou comunidades esse problema é mais fácil de ser resolvido, pois a quantidade de lixo produzido é bem inferior e é mais fácil de ser tratado.

Isso somente se referindo ao lixo orgânico, ainda é produzido o "lixo seco", papéis, vidros, latas, todos esses materiais podem e devem ser reaproveitados. Além de se dar uma destinação correta e adequada, pode se tornar uma atividade econômica muito lucrativa.

A reciclagem desses produtos, gera novos empregos, reduz o consumo de recursos naturais, gera uma economia de energia, sem contar que as indústrias pagariam para se livrar dos resíduos que são produzidos em seu processo industrial.

\subsection{Lixo Seco}

Um outro produto resultante na produção dos resíduos é o chamado lixo seco, constituído de papel, vidro, plástico, entre outros materiais. O biodigestor é uma excelente alternativa para o lixo orgânico, mas é uma solução somente para uma parte dos problemas que são acarretados com o lixo. É preciso 
encontrar a solução para lixo seco, na verdade, essa solução é tão simples como a construção do Biodigestor. A reciclagem de material é uma prática conhecida há muitos anos e pouco efetivada. A utilização dessa técnica pode trazer benefícios sócio-econômicos e financeiros para a comunidade.

Antes de abordar a reciclagem como tema, é necessário abordar a "Fórmula dos RE's", do qual o processo de reciclar faz parte. REduzir, REutilizar e REciclar, a combinação desses fatores, é fundamental para conscientização para uma prática mais conservacionista dos recursos naturais. Essa fórmula, pode e deve ainda ser ampliada, se aprofundarmos os conceitos em termos de diminuir o consumo de materiais, pode-se acrescentar a essa fórmula mais alguns RE;s, como por exemplo: REpensar os hábitos de consumo, REcuperar materiais e ainda Reeducarmos, mudando assim velhas formas de conduta e comportamento. Porém, será abordado como tema, somente a reciclagem. ${ }^{7}$

\subsection{Reciclar:}

É o processo de retornar os resíduos sólidos e a sucata em matéria prima e ou produto final, por meio de manufaturamento ou por um processo de industrialização. Em outras palavras, é utilizar o lixo que ia ser jogado fora, depositado em lugares inadequados, em algum produto útil ou que possa ser vendido a outras pessoas ou turistas ${ }^{8}$.

A criação de cooperativas para reciclagem é uma das soluções. Utilizar o lixo como matéria prima, na produção de outros produtos é a premissa básica da reciclagem, dessa forma se ganha dos dois lados. Primeiro na destinação do lixo, economizando nos gastos de transporte e tratamento do lixo. Segundo é a compra de matéria prima barata, fazendo com que o produto final tenha um menor custo na produção, tornando-o o mais com competitivo,

\footnotetext{
${ }^{7}$ Dados obtidos no seguinte site: http://www.recycle.hpg.ig.com.br/index.html

${ }^{8}$ Dados obtidos no seguinte site: http://www.recycle.hpg.ig.com.br/index.html
} 
aumentado o ganho na hora da venda e ainda abrindo novas frentes de trabalho.

O processo de reciclagem será mais bem aproveitado se um outro processo ou um novo comportamento for inserido no cotidiano das pessoas. A coleta seletiva, nada mais é o coletar o material devidamente separado pela fonte geradora. Este sistema facilita a reciclagem porque o material permanece limpo e com maior potencial de reaproveitamento.

Para que um programa de Coleta Seletiva e Reciclagem de material, possa vir a funcionar e ter êxito em seu objetivo, deverá haver uma contribuição de toda a comunidade, e somente com a demonstração dos resultados de tal programa as pessoas passarão a acreditar e dar crédito ao programa. Normalmente a situação que é encontrada é a seguinte: é feita uma grande campanha para que as pessoas separem o lixo sólido em diferentes recipientes, só que na hora da coleta do lixo devidamente separado é enviado um único caminhão, onde todo o lixo é jogado no mesmo lugar, invalidando o trabalho que as pessoas tiveram em separar o material em casa. É o fracasso do programa de coleta seletiva. Uma nova consciência ou novas atitudes em relação ao meio ambiente, não serão mudadas bruscamente, esse novo padrão de comportamento esperado, só será alcançado a partir de política de conscientização e a introdução de um novo paradigma, no qual reflete a importância da conservação do meio ambiente.

\subsection{Educação Ambiental}

A educação ambiental no Brasil não é somente uma proposta de ensino, mas sim, uma Lei que foi sancionada pelo Presidente Fernando Henrique Cardoso em 27 de abril de 1999. A Lei N. 0705, foi proposta pelo Deputado Federal Fábio Feldmann e reconhece a Educação Ambiental como um componente urgente, essencial e permanente em todo o processo do educativo do país. 
A Política Nacional de Educação Ambiental é uma proposta programática de promoção da educação ambiental em todos os setores da sociedade. Diferente de outras Leis, não estabelece regras ou sanções, mas estabelece responsabilidades e obrigações.

Ao definir responsabilidades e inserir na pauta dos diversos setores da sociedade, a Política Nacional de Educação Ambiental institucionaliza a educação ambiental, legaliza seus princípios, transforma-a em objeto de políticas públicas, além de fornecer à sociedade um instrumento de cobrança para a promoção da educação ambiental.

Apesar da Política Nacional de Educação Ambiental, ter sido sancionada somente em 1999, o pensamento sobre a educação ambiental já era tema de discussão há muitos anos atrás. Veja os exemplos:

"Desenvolver um cidadão consciente do ambiente total, preocupado com os problemas associados a esse ambiente e que tenha o conhecimento, as atitudes, motivações, envolvimento e habilidades para trabalhar individual e coletivamente para resolver problemas atuais e prevenir os futuros." Carta de Belgrado, 1975.

Veja os objetivos da Educação Ambiental que foram elaborados na Conferência de Tbilisi. $^{9}$

1. O desenvolvimento de consciência e sensibilidade para problemas locais e globais;

2. O aumento de conhecimentos sobre o ambiente e seus problemas associados;

3. Mudanças de atitudes e valores que motivem ações;

\footnotetext{
${ }^{9}$ UNESCO. La Educacion Ambiental. Lãs Grandes Orientaciones de La Conferencia de Tbilisi. Paris. 1980.
} 
4. O desenvolvimento de capacidades que ajudem a identificar e resolver problemas ambientais.

Vejamos ainda o que se diz no Brasil sobre a educação ambiental:

"Cabe ao Poder Público promover a Educação Ambiental em todos os níveis de ensino e a conscientização pública para a preservação do meio ambiente"10

"Entendem-se por educação ambiental os processos por meio dos quais o indivíduo e a coletividade constroem valores sociais, conhecimentos, habilidades, atitudes e competências voltadas para a conservação do meio ambiente, bem de uso comum do povo, essencial à sadia qualidade de vida e sua sustentabilidade"

"A educação ambiental é um componente essencial e permanente da educação nacional, devendo estar presente, de forma articulada, em todos os níveis e modalidades do processo educativo, em caráter formal e não-formal" 11

Embora o tema da Educação Ambiental há muitos anos tenha um lugar de destaque em discussões internacionais, Brasil sancionou uma política sobre Educação Ambiental somente há poucos anos, ressaltando assim a sua importância. Porém, não existe a aplicação na prática de tal política. Existem alguns projetos em andamento no Brasil, principalmente por parte de ONG's e por uma minoria da sociedade organizada. Esses projetos são importantes e de valor, porém, não atingem a maioria da população, fazendo com que a atual política seja ineficaz para atingir o objetivo para qual ela foi criada.

Enquanto não houver uma mudança na forma de pensar de toda a população e nas políticas de saneamento das cidades, o lixo, continuará a ser

\footnotetext{
${ }^{10}$ Artigo 225, Inciso VII da Constituição Federal de 1988

${ }^{11}$ Lei n. ${ }^{\circ} 9.795$ de 27 de abril de 1999 - Art. $2^{\circ}$
} 
jogado a céu aberto, sem nenhum tipo de tratamento ou cuidado. Continuará acarretando sérios riscos à saúde da população e ao meio ambiente. Um grande exemplo disso foi à contaminação por Césio 147, que ocorreu na cidade de Goiânia, capital do Estado do Goiás. Após uma pessoa ter exposto o material radioativo encontrado em uma máquina de Raio-X que foi jogada fora, em um aterro da cidade, causando a morte de pessoas e um grande prejuízo a cidade.

O saneamento básico é de responsabilidade da cidade, mas a destinação adequada e limpeza das ruas são de responsabilidade de todos. A reciclagem de material é uma solução que pode ser viável economicamente e ambientalmente correta, falta colocar em prática um programa de reciclagem.

\subsection{Biodigestor - Alternativa Viável}

A origem do biodigestor é bastante antiga, os povos antigos essencialmente agrícolas como no caso os Hindus, já utilizavam esse método de decomposição, mas foram os chineses e japoneses, que trouxeram esta tecnologia rudimentar até os dias de hoje. $\mathrm{Na}$ realidade não houve muitas mudanças desde os primórdios até os tempos atuais.

Os agricultores faziam a limpeza do terreno e colocavam o lixo em um canto do terreno e muitas vezes o enterravam para dar fim a esse material. Com isso passaram a observar a decomposição da matéria orgânica e então começaram a dirigir ou administrar este sistema de limpezas. Passaram a fazer covas ou trincheiras, em outros termos grandes valas onde todo 0 material era jogado, restos de frutas, dejetos humano e animal, águas sujas, tocos de velhas árvores ou restos vegetais, etc.

Com o passar do tempo eles foram cobrindo de areia por causa dos insetos que se concentravam e foram observando a formação de gás. Um gás que repetia fenômenos observados em pântanos que por coincidência é o mesmo gás ou seja o Biogás ( METANO ). 
A finalidade inicial do digestor, era o de produzir adubo, para ser utilizado nas plantações, ajudando assim a manter as propriedades do solo. Conseqüentemente alguém descobriu que o gás poderia ser utilizado também e isto abriu caminho para a criação de diversos tipos de Biodigestores que poderiam ser classificados como biodigestores verticais e horizontais.

Hoje estes Biodigestores se resumem a dois modelos agrícolas mais famosos. O modelo Indiano e o modelo Chinês. Os demais são variantes apenas, ainda que apresentem uma tecnologia apurada.

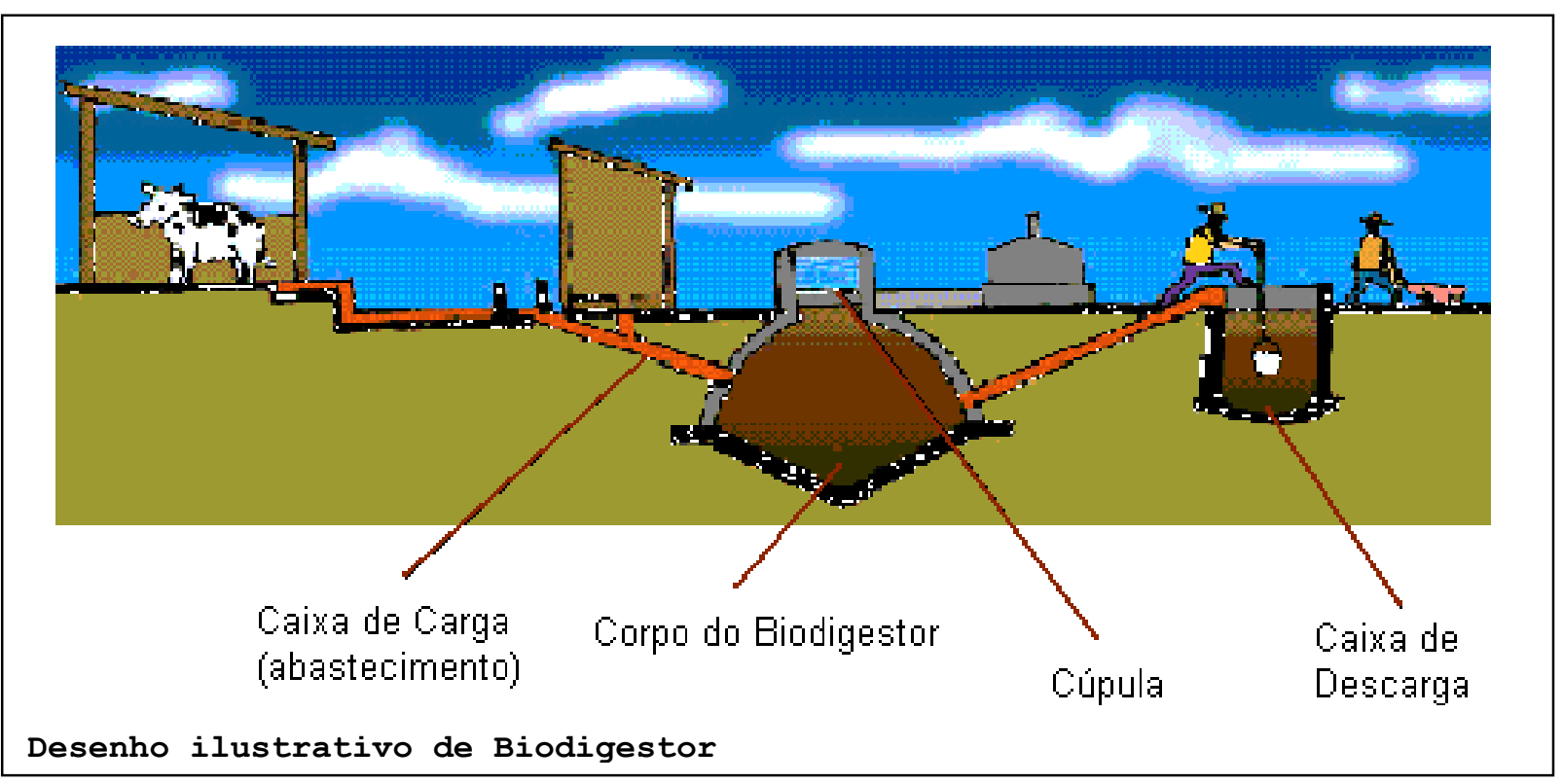

No Brasil por volta das décadas de 60 e 70 foi muito intensificado o estudo sobre Biodigestores. A Marinha brasileira desenvolveu um estudo completo e também as principais universidades e centros de tecnologia agrícola do país. No Brasil existem 3 tipos básicos de biodigestores, o modelo Chinês, o modelo Indiano e o modelo da Marinha. Os três modelos de biodigestor apresentam semelhanças entre si, todos têm ligados ao corpo do biodigestor uma caixa de carga, por onde o biodigestor é abastecido e uma caixa de descarga, utilizada para retirada da matéria sólida. A diferença entre os três modelos está basicamente como cada foi construído e no tipo de cúpula utilizada. Vejamos essas diferenças e algumas vantagens e desvantagens desses 3 modelos. 


\section{Modelo Indiano}

A cúpula do modelo Indiano geralmente é feita de ferro e se move para cima e para baixo, são utilizados pesos (pedras) sobre a cúpula para poder fazer pressionar o gás retido no interior do biodigestor. Esse processo permitira o gás sair com pressão suficiente para abastecer certos equipamentos.

\section{a)Vantagens:}

- O digestor do modelo indiano é construído enterrado no solo e, como a temperatura do solo é pouco variável, o processo de fermentação que ocorre em seu interior tem a vantagem de sofrer pouca variação de temperatura. A temperatura elevada favorece a ação das bactérias (responsáveis pelo processo de fermentação anaeróbica) e a sua queda provoca uma menor produção de biogás.

- Ocupa pouco espaço do terreno (em relação ao da marinha), porque sua maior extensão é vertical.

- Em termos de custos, sendo as paredes de seu digestor construídas dentro do solo, o modelo dispensa o uso de reforços, tais com cintas de concreto, o que barateia os custos.

\section{b)Desvantagens :}

- Quando a cúpula for de metal, ela está sujeita à corrosão. Recomenda-se fazer uma boa pintura com um antioxidante, com por exemplo, o zarcão.

- O custo da cúpula, que o modelo chinês não tem e o da marinha é mais baixo. 
- O sistema de comunicação entre a caixa de carga e o digestor, sendo feito através de tubos, pode ocorrer entupimentos.

- Sua construção é limitada para áreas de lençol freático alto, ou seja, não é um modelo indicado para terrenos superficiais, pois nestes casos pode ocorrer infiltração.

\section{Modelo Chinês}

O modelo Chinês é uma peça única, projetado para não ocupar espaço, esse modelo é enterrado, permitindo assim a utilização do terreno em sua volta. Não é necessário nenhum tipo de artifício para fazer pressão o gás, o próprio biofertilizante que é produzido dentro do biodigestor serve como peso, fazendo assim que o gás saia sob pressão.

\section{a)Vantagens :}

- Este modelo tem um custo mais baixo em relação aos outros, pois a cúpula é feita de alvenaria.

- O biodigestor chinês é o que ocupa menos espaço na superfície do solo.

- Como é construído completamente enterrado no solo (tanto o biodigestor, como o gasômetro), sofre muito pouca variação de temperatura.

\section{b)Desvantagens :}

- O sistema de comunicação entre a caixa de carga e o biodigestor, sendo feito através de tubos, está sujeito a entupimentos.

- Tem limitação ao tipo de solo. Sua construção em solos superficiais não é indicada. 
- Não é um biodigestor próprio para acúmulo de gás, devido a sua construção de cúpula fixa (a área de reserva de gás é menor). É um modelo mais indicado na produção de biofertilizante.

\section{Modelo da Marinha}

O modelo da Marinha é do tipo horizontal, tendo a sua largura maior que a profundidade, ficando mais exposto ao Sol, o que acarreta uma maior produção de gás. Sua cúpula é de plástico maleável (PVC), infla como um balão, de acordo com a quantidade de gás produzido. Para ajudar a dar pressão ao gás, normalmente são utilizados sacos de areia ou pneus velhos sobre a cúpula, aumentando a pressão do gás.

\section{a)Vantagens :}

- A área sujeita à exposição solar é maior, porque sua cúpula em relação aos outros modelos é maior, facilitando com isto uma maior produção de gás nos dias quentes.

- Sua construção não exige restrições a tipo de solo, pois além de não exigir solos profundos porque é um modelo de tipo horizontal (sua maior extensão é horizontal), seu biodigestor tanto pode ser construído enterrado, como também sobre a superfície do solo.

- A comunicação da caixa de carga para o biodigestor, feita de alvenaria, é mais larga, evitando com isso entupimento e facilitando a manutenção.

- A limpeza do biodigestor é mais fácil porque a cúpula, sendo de lona de PVC, é mais fácil de ser retirada. 


\section{b)Desvantagens :}

- Neste modelo, como no Indiano, temos o alto custo da cúpula.

\subsection{Biogás}

"O Biogás é um gás inflamável produzido por microorganismos, quando matérias orgânicas são fermentadas dentro de determinados limites de temperatura, teor de umidade e acidez, em um ambiente impermeável ao ar"12.

O metano, principal componente do biogás, não tem cheiro, cor ou sabor, mas os outros gases presentes conferem-lhe um ligeiro odor de alho ou de ovo podre. O peso do metano é pouco mais da metade do peso do ar.

O Biogás , também é conhecido em outros países como "gorba gás " ou gás de dejetos. Vários são os fatores que influenciam para sua formação, tais como:

- O tipo de biodigestor;

- A temperatura da região;

- O tipo de alimento orgânico;

- O tempo de fermentação;

- A carga utilizada no biodigestor.

Geralmente a sua composição é: ${ }^{13}$

- metano - 55 a $66 \%$;

- dióxido de carbono - 35 a 45\%;

- nitrogênio - 0 a 3\%;

- hidrogênio - 0 a 1\%;

- oxigênio - 0 a 1\%;

- gás sulfídrico - 0 a $1 \%$.

\footnotetext{
${ }^{12}$ Fonte: http://www.energiahp.hpg.ig.com.br/biodig.htm

${ }^{13}$ Fonte: http://www.energiahp.hpg.ig.com.br/biodig.htm
} 


\subsection{Produção de Biogás ${ }^{14}$}

Fases da Decomposição : A decomposição bacteriana de matéria orgânica sob condições anaeróbicas é feita em três fases: 1) fase de hidrólise; 2) fase ácida; 3) fase metagênica.

Fase de hidrólise - Nesta fase as bactérias liberam no meio as chamadas enzimas extracelulares, as quais irão promover a hidrólise ${ }^{15}$ das partículas e transformar as moléculas maiores em moléculas menores e solúveis ao meio.

Fase Ácida - Nesta fase, as bactérias produtoras de ácidos transformam moléculas de proteínas, gorduras e carboidratos em ácidos orgânicos (ácido láctico, ácido butílico), etanol, amônia, hidrogênio e dióxido de carbono e outros.

Fase Metanogênica - As bactérias metanogênicas atuam sobre 0 hidrogênio e o dióxido de carbono, transformando-os em metanol ( $\mathrm{CH} 4)$. Esta fase limita a velocidade da cadeia de reações devido principalmente à formação de microbolhas de metano e dióxido de carbono em torno da bactéria metanogênica, isolando-a do contato direto com a mistura em digestão. Razão pela qual a agitação no digestor é prática sempre recomendável, através de movimentos giratórios do gasômetro.

O desempenho do biodigestor em produzir gás depende das diversas populações bacterianas e de fatores não biológicos com os quais os organismos estão ligados.

\subsection{Bactérias ${ }^{16}$}

As bactérias que participam do processo de fermentação para a produção do biogás estão compreendidas em dois grupos; as bactérias do

\footnotetext{
${ }^{14}$ Fonte: http://www.energiahp.hpg.ig.com.br/biodig.htm

${ }^{15}$ Hidrólise. Decomposição de uma molécula pela ação da água.

${ }^{16}$ Fonte: http://www.energiahp.hpg.ig.com.br/biodig.htm
} 
ácido fórmico e as bactérias gaseificantes também identificadas como metanogênicas.

O primeiro grupo inicia o processo e são bactérias não muito sensíveis ao oxigênio e que produzem dióxido de carbono. Em outras palavras o sistema tem o seu início com a ação de bactérias aeróbias que se alimentam da matéria orgânica produzindo dióxido de carbono. Elas se reproduzem facilmente em condições diversas de temperatura, pressão e meio químico. Provenientes do ácido fórmico, torna-se bastante fácil a sua presença em dejetos orgânicos animais e vegetais.

Com isso a presença de gás carbônico e ausência fundamental do oxigênio do ar, fazem com que bactérias num meio anaeróbio, começassem a se desenvolver absorvendo o gás carbônico e produzindo metano. Existem muitas controvérsias a respeito das bactérias metanogênicas, pois existem diversas substâncias que são formadas devido a acidentes de fermentação assim como fermentação acéticas, isobutílicas, isopropílicas e etc, e para um determinado grupo de estudiosos, só existe um grupo de bactérias aeróbias e um grupo de bactérias anaeróbias. Em outras palavras bactérias que respiram oxigênio e produzem $\mathrm{CO} 2$ e bactérias que respiram $\mathrm{CO} 2$ e produzem metano.

\subsection{O Biofertilizante ${ }^{17}$}

Depois de passarem no biodigestor, os resíduos resultantes apresentam alta qualidade para uso como fertilizante agrícola, devido principalmente aos seguintes aspectos:

- Diminuição no teor de carbono do material, pois a matéria orgânica ao ser digerida perde exclusivamente carbono na forma de $\mathrm{CH} 4$ e $\mathrm{CO} 2$;

- Aumento no teor de nitrogênio e demais nutrientes, em conseqüência da perda do carbono;

\footnotetext{
${ }^{17}$ Fonte: http://www.energiahp.hpg.ig.com.br/biodig.htm
} 
- Diminuição na relação $\mathrm{C} / \mathrm{N}$ da matéria orgânica, o que melhora as condições do material para fins agrícolas;

- Facilidades de imobilização do biofertilizante pelos microrganismos do solo, devido ao material já se encontrar em grau avançado de decomposição, o que vem aumentar a eficiência do biofertilizante, solubilização parcial de alguns nutrientes.

As condições ótimas de vida para os microorganismos anaeróbios são:

\section{a) Impermeabilidade ao Ar:}

Os microorganismos anaeróbicos utilizados na decomposição de matéria orgânica, não exigem oxigênio, para suas atividades biológicas, que são muitos sensíveis em sua presença.

A decomposição de matéria orgânica na presença de oxigênio produz dióxido de carbono (CO2); na ausência de ar (oxigênio) produz metano. Se o biodigestor não estiver perfeitamente vedado a produção de biogás é inibida.

\section{b) Temperatura Adequada:}

A temperatura no interior do digestor afeta sensivelmente a produção de biogás. Qualquer variação térmica acima de $30 \mathrm{C}$, pode afetar a produção do biogás.

Em clima tropical onde a temperatura é praticamente constante com média acima de $20^{\circ} \mathrm{C}$, Os biodigestores dispensam sistemas adicionais para aquecimento. Entretanto, em regiões onde a temperatura cai, durante um certo período do ano, esses sistemas são necessários. O aquecimento do biodigestor pode ser feito via interna, externa e/ou chama direta. O próprio gás pode e deve ser utilizado para o aquecimento. 


\section{c) Nutrientes:}

Os principais nutrientes dos microorganismos são carbono, nitrogênio e sais orgânicos. A principal fonte de nitrogênio são as dejeções humanas e de animais, enquanto que os polímeros presentes nos restos de culturas representam o principal fornecedor de carbono. A produção de biogás não é bem sucedida se apenas uma fonte de material for utilizada.

\section{d) Teor de Água:}

O teor de água deve normalmente situar-se em torno de $90 \%$ do peso do conteúdo total. Tanto o excesso, quanto a falta de água são prejudiciais. O teor da água varia de acordo com as diferenças apresentadas pelas matériasprimas destinadas à fermentação. 


\section{METODOLOGIA}

O método utilizado para realização desse frabalho foi a seguinte;

1. Pesquisa secundária. Levantamento de dados pertinentes ao trabalho. Pesquisa de em material impresso, como: livros, revistas e manuais técnicos.

A bibliografia impressa se destaca pelo fato de terem sido utilizadas informações de uma amplitude temporal superior a 20 anos, desde manuais do ano de 1981 a livros mais recentes do ano de 2002.

2. Pesquisa com a utilização da Internet. Foram consultados diversos sites, todos relacionados ao trabalho desenvolvido. Utilizando o "google", no endereço eletrônico www.google.com.br. Esse site de busca permitiu encontrar um material muito útil e farto para o trabalho. A partir do uso de palavras chaves, tais como: biodigestor, lixo, ecoturismo, reciclagem, etc. Foi possível encontrar textos interessantes e de qualidade.

3. Analise da Dados. Após o levantamento de dados, iniciou-se a analise, compilação e ordenamento das informações. Essa etapa foi desenvolvida ao longo de aproximadamente 4 meses, período no qual foi redigido esse trabalho.

4. Por último, mas não menos importante, foram feitos os ajustes e correções necessários, permanecendo assim o atual conteúdo e formato dessa monografia. 


\section{RESULTADOS DA DISCUSSÃO}

Com a introdução dos biodigestores em áreas onde o ecoturismo está se desenvolvendo, um dos principais atributos desse sistema é produzir o biogás, vejamos alguns usos e vantagens desse gás.

\subsection{Uso do Biogás}

O biogás por ser extremamente inflamável, oferece condições para uso:

- em fogão doméstico;

- em lampião;

- como combustível para motores de combustão interna;

- em geladeiras;

- em chocadeiras;

- em secadores de grãos ou secadores diversos;

- na geração de energia elétrica.

O biogás pode ainda servir para aplicações que servem tanto para a indústria quanto para a agroindústria na aplicação em:

- processos de dessalinização;

- unidades de energia elétrica;

- unidades estáticas para obtenção de energia mecânica;

- sistemas de refrigeração;

- sistemas de secagem e cristalização;

- sistemas injetores de gás p/ processos de calefação;

- propulsão de motores estacionários;

\subsection{Vantagens do Biogás}

1. A produção de biogás representa um avanço importante para solucionar o problema da falta de disponibilidade de combustível no meio rural. Por conseguinte, interessar a toda a população nele residente. 
2. A redução das necessidades de lenha poupa as matas. A produção de biogás representa um importante meio de estímulo a agricultura, promovendo a devolução de produtos vegetais ao solo e aumentando o volume e a qualidade de adubo orgânico. Os excrementos fermentados aumentam o rendimento agrícola.

3. O biogás, substituindo o gás de petróleo no meio rural, elimina também os custos do transporte de gás de cozinha.

4. O uso do biogás na cozinha é higiênico, não desprende fumaça e não deixa resíduos nas panelas. As donas de casa ficam livres de pesadas tarefas domésticas, de mobilizar carvão e lenha para a cozinha.

5. O desenvolvimento de um programa de biogás também representa um recurso eficiente para tratar os excrementos e melhorar a higiene e o padrão sanitário do meio rural.

\subsection{Vantagens do Biogás para o Ecoturismo}

1. Conservação de matas nativas e florestas. Com a utilização do biogás, que é acessível a toda população, não será mais necessário o uso de lenha para cozimento de alimentos ou como fonte de calor.

2. Diminuição da contaminação do solo, lençóis freáticos e de rios. Com a introdução do biodigestor o lixo e o esgoto terão um tratamento adequado, evitando assim a contaminação do meio ambiente.

3. Incremento na produção de verduras, legumes e hortaliças, a partir do uso do adubo orgânico, podendo ofertar aos visitantes e a própria comunidade alimentos saudáveis e de excelente qualidade, melhorando o nível do atendimento nos serviços de alimentação. 
4. Oferta de serviço básico de fornecimento de energia elétrica, sem causar danos à natureza. A comunidade e os visitantes terão acesso à luz elétrica, banho quente, uso de aparelhos que demandam energia elétrica e outros itens de conforto da vida moderna e com a certeza de que a fonte de energia é limpa e renovável.

5. Acesso a água potável, a partir do bombeamento de poços artesianos.

6. Todas as vantagens acima estão diretamente ligadas ao biodigestor e o biogás, mas ainda existem outras vantagens, por exemplo a melhoria da qualidade de vida da população, melhoria da alimentação, uma menor possibilidade de doenças por exposição ao esgoto ou por água contaminada.

7. Ainda temos a vantagem do marketing e da propaganda gerada. $\mathrm{O}$ fato de existir uma localidade que reaproveita o lixo e o próprio esgoto da cidade e transforma esse resíduo em fonte de energia e gerar benefícios para a população, essa cidade se torna por si só, um grande atrativo para o ecoturismo, capaz de atrair diversos visitantes. Pessoas que virão dos mais variados lugares, viajarão para poder conhecer e experimentar o modo de vida das pessoas que vivem em uma cidade que apresenta tamanha organização e preocupação com o ambiente.

\subsection{Alternativas para o Lixo}

O ecoturismo é mais que uma simples forma de conservar ambientes naturais. Como é visto por algumas pessoas, essa atividade é mais ampla e abrangente do que isso. O ecoturismo é primeiramente uma atividade econômica, com objetivo de gerar lucro, é claro que como se trata de atividade desenvolvida em meio à natureza, a conservação dessas áreas deve ser levada em consideração e não esquecendo os fatores humanos e sociais que compõem essa atividade. 
É bastante simples compreender que não é possível praticar ecoturismo em locais que contenham lixo, onde são produzidos odores ruins, uma visão desagradável e o que é pior, onde o ambiente está sendo visivelmente degradado. Esse problema com o lixo em sua maioria é provocado pelos próprios visitantes.

Um outro agravante na produção de lixo é o rápido e desordenado crescimento de algumas cidades. Na pressa de se criar uma infra-estrutura que possa atender a um número maior de visitantes, os sistemas de esgoto, abastecimento de água e coleta de lixo, ficam prejudicados, otimizando o problema do lixo.

São diversas as alternativas existentes para se tratar o lixo, mas pouquíssimas são aplicadas ou levadas em consideração. Opções tais como: Educação Ambiental; redução na produção de lixo; coleta seletiva; reciclagem e utilização de biodigestores, são processos e procedimentos conhecidos, porém não divulgados ou postos em prática.

O fato é que o lixo jamais deixará de ser produzido, até pode ser reduzido, mas a destinação deve ser repensada. São grandes as vantagens geradas na utilização de processos preventivos no tratamento do lixo, gasta-se muito mais com o processamento convencional do lixo do que com um tratamento mais preventivo. A economia de energia elétrica e de recursos naturais, são infinitamente maiores no processo de reciclagem.

Para ser ter uma idéia das vantagens obtidas, veja o seguinte exemplo: O alcance da produção de energia dos biodigestores, pode ser avaliado tomando a produção dos biodigestores instalados na China até dezembro de 1979. Todos juntos produziram um valor energético equivalente a 14,5 "Itaipus" ${ }^{18}$. O poder calórico do biogás, pode facilmente substituir a queima de combustível fóssil.

$\overline{18}$ Fonte: http://www.energiahp.hpg.ig.com.br/biodig.htm 
A má administração do lixo afeta diretamente a qualidade de vida de uma comunidade inteira e conseqüentemente afeta o turismo. Ninguém está disposto a pagar para ver lixo nas ruas. Esse problema pode acarretar inúmeros prejuízos a economia de uma cidade ou região. Cidades onde ocorre o problema com o lixo, ou seja, cidades sujas, deixam uma marca negativa, difícil de ser apagada. As próprias instituições ligadas ao turismo, como a EMBRATUR e Secretarias de Turismo, lançam mão de campanhas educativas, para tentar sanar o problema do lixo nas ruas.

Apesar dessas campanhas serem úteis, estão longe de serem ideais, pois não adianta somente "varrer o lixo para debaixo do tapete", o lixo que é produzido é tirado das ruas turísticas e jogado nos lixões e esse procedimento é errado e irresponsável.

O lixo não tratado, ou amontoado em aterros, produz sérios problemas:

- Contaminação do solo;

- Contaminação das águas e lençóis freáticos;

- Atrai animais nocivos;

- Produz odores desagradáveis;

- Polui os rios;

- Gera problemas de saúde;

Esses são apenas alguns dos problemas causados pelo lixo não tratado.

Existe uma relação muito próxima do ecoturismo com o meio ambiente. No geral as pessoas praticantes dessa modalidade de viagem têm uma preocupação com meio ambiente. Os ecoturistas preferem visitar áreas que a população está preocupada com a conservação e preservação dos atrativos naturais e culturais. O perfil dos ecoturistas ainda não foi traçado com precisão, mas as pessoas estão dispostas a visitar áreas realmente conservadas e localidades preocupadas com o meio ambiente, mesmo que isso signifique pagar valores mais altos. 
"As pesquisas realizadas com turistas, bem como o próprio comportamento do turista, sugerem que o preço é um fator relativamente irrelevante na escolha de um roteiro ecológico, e que, mesmo quando o preço é um problema os turistas estão dispostos a pagar altas taxas se sabem que elas estão sendo utilizadas para enriquecer sua experiência ou para conservar a área específica que estão visitando". (Lindberg. Donald,. 1999: 151).

É explicito que o lixo acarreta prejuízos sociais, financeiros, econômicos e ambientais, mas também é bem fácil encontrar uma série de alternativas para combater esses problemas. 


\section{CONCLUSÃO}

A população mundial vem crescendo a cada ano e com ela a violência, o aumento da densidade demográfica, a competição, as responsabilidades e engarrafamentos.Todos esses fatores são geradores de ansiedade e estresse. Juntamente com a rotina do dia-a-dia com a qual as pessoas convivem diariamente, surgiram também novas necessidades geradas pela vida moderna, como poder relaxar, sair de férias e descansar.

Como as realidades das grandes cidades são semelhantes, a alternativa de fugir de toda essa confusão passou a ser as pequenas cidades do interior e os ambientes naturais.

O aumento de visitas à natureza, acarreta benefícios ao meio ambiente e às comunidades vizinhas a essas áreas, mas também gera diversos prejuízos, como a produção do lixo.

Essa produção do lixo pode causar transtornos, mas também trazer benefícios, depende de como essa questão vai ser administrada.

Foram apresentadas algumas soluções para o lixo produzido em pequenas quantidades. Soluções essas que além de resolver o problema do lixo, pode gerar uma série de vantagens e benefícios para a comunidade, meio ambiente e aos ecoturistas, tais como.

- Eliminação do lixo;

- Geração de renda;

- Diminuição da contaminação do solo, rios e lençóis freáticos;

- Produção de combustível natural;

- Produção de adubo orgânico;

- Possibilidade de auto-suficiência energética;

- Melhoria do saneamento básico. 
Esses são apenas alguns exemplos das vantagens diretas que podem ser geradas e não foram levadas em conta as vantagens indiretas.

O objetivo do trabalho, foi o de apresentar, alternativas para uma destinação adequada para o lixo.

Essas alternativas estão disponíveis, reais, viáveis e perfeitamente executáveis, basta por em prática. 


\section{BIBLIOGRAFIA}

BARRETO, Margarita. Manual de Iniciação ao Estudo do Turismo. 2ª . Edição. Campinas/SP. Editora Papirus, 1997.

CONSTITUIÇÃO FEDERAL 1988 - Republica Federativa do Brasil. Edição atualizada em 1995.

IGNARRA, Luiz Renato. Fundamentos do Turismo. São Paulo/SP. Editora Pioneira, 1999.

JUSTIANO, Eduardo Félix. Ecoturismo e Ecoturista In Outdoor Magazine. São Paulo/SP. Ano 2, 1998: Disponível em:

www.arteweb.com.br/ecoturismo/definicao.htm - acesso em: 30 set. 1999.

LINDBERG, Kreg e HAWKINS, Donald E. Ecoturismo: Um Guia para Planejamento e Gestão. 2a . Ed. São Paulo/SP. Editora Senac, 1995.

REVISTA: Integração - Ensino, Pesquisa e Extensão. São Paulo/SP Suplemento 01/99 - Outubro/99.

Disponível em: www.recycle.hpg.ig.com.br/index.html - acesso: 26 out. 2002.

ROCHA, Ana Augusta e LINSKER, Roberto. Brasil Aventura - Ilhas. São Paulo/SP. Editora Terra Virgem, 1996.

SERRANO, Célia Maria de Toledo e BRUHNS, Heloisa Turini. Viagens à Natureza: Turismo, Cultura e Ambiente. Campinas/SP. Ed. Papirus. 1997.

SILVA, Normando Alves da. Manual Técnico: Construção e Operação de Biodigestor - Modelo Chinês. Brasília/DF. Convênio: MME/MA/EMBRATER. 1981. 
UNESCO. La Educacion Ambiental. Lãs Grandes Orientaciones de La Conferencia de Tbilisi. Paris. 1980. SITE: www.aipa.org.br/ea-trat2-tiblisiparcial-1977.htm - acesso: 20 jan 2003

SITE: www.cecae.usp.br/aprotec/RESP64.htm - acesso: 15 jan 2003.

SITE: www.compam.com.br/oquelixo.htm - acesso: 17 jan 2003.

SITE:www.demec.ufmg.br/port/d online/diario/ema003/gasosos/biogas/exempl os.htm - acesso: 15 jan 2003.

SITE: www.energiahp.hpg.ig.com.br/biodig.htm - acesso: 15 jan 2003.

SITE: www.inventabrasil.hpg.ig.com.br/biodigr.htm - acesso: 15 jan 2003.

SITE: www.lixo.com.br/home.html - acesso: 15 jan 2003.

SITE: www.mma.gov.br/port/sdi/ea/Cbelg.cfm - acesso: 20 jan 2003, 